\title{
PENYULUHAN TENTANG MENULIS KARYA ILMIAH BAGI GURU GURU SDN GUGUS VI KECAMATAN GERUNG LOMBOK BARAT TAHUN 2021
}

\author{
Radiusman'1), Ida Bagus Kade Gunayasa1), Sudirman'), Abdul Kadir Jaelani'), Hasnawati1) \\ 1)Pendidikan Guru Sekolah Dasar, FKIP, Universitas Mataram, Nusa Tenggara Barat, Indonesia \\ Corresponding author : Radiusman \\ E-mail : radius_saragih88@unram.ac.id
}

Diterima 05 Oktober 2021, Direvisi 25 Oktober 2021, Disetujui 25 Oktober 2021

\begin{abstract}
ABSTRAK
Penulisan karya tulis ilmiah merupakan suatu hal yang wajib bagi guru, namun masih banyak guru yang belum melaksanakan hal tersebut. Untuk mengatasi hal tersebut, maka perlu dilakukan suatu kegiatan kolaborasi antara pihak sekolah dengan instansi pendidikan, khususnya perguruan tinggi dalam bentuk kegiatan pengabdian kepada masyarakat. Kegiatan pengabdian kepada masyarakat ini bertujuan untuk memberikan penyuluhan tentang bagaimana cara menulis karya tulis ilmiah bagi guru-guru SDN gugus VI Kec. Gerung. Metode pelaksanaan kegiatan pengabdian ini menggunakan tahap koordinasi, observasi, komunikasi dan sosialisasi. Pelaksanaan kegiatan pengabdian ini dilakukan pada masa pandemi Covid-19 sehingga pelaksanaan harus dilakukan menggunakan protokol kesehatan 3M. Materi yang disampaikan pada kegiatan pengabdian ini adalah teknik menemukan permasalahan penelitian, ketatabahasaan karya ilmiah dan konsep penulisan karya ilmiah. Kegiatan ini berlangsung dengan lancar dan dihadiri oleh 38 orang yang terdiri dari 6 tim pengabdi dan 32 orang guru. Hasil dari kegiatan pengabdian ini adalah guru mulai menyadari pentingnya menulis karya ilmiah untuk meningkatkan profesionalitas serta meningkatkan kemampuan siswa. Berdasarkan hasil wawancara dengan guru peserta kegiatan diperoleh informasi bahwa perlu diadakannya kegiatan lanjutan berupa pendampingan dalam penulisan karya ilmiah.
\end{abstract}

Kata kunci: kegiatan PKM; karya tulis ilmiah; penyuluhan.

\begin{abstract}
Writing scientific papers is mandatory for teachers, but there are still many teachers who have not implemented it. To overcome this, it is necessary to carry out collaborative activities between the school and educational institutions, especially universities in the form of community service activities. This community service activity aims to provide counseling on how to write scientific papers for SDN Cluster VI Kec. Gerung. The method of implementing this service activity uses the stages of coordination, observation, communication and socialization. The implementation of this service activity was carried out during the Covid-19 pandemic so it had to be carried out using the $3 \mathrm{M}$ health protocol. The material presented in this service activity is the technique of finding research problems, the grammar of scientific papers, and the concept of writing scientific papers. This activity ran smoothly and was attended by 38 people consisting of 6 service teams and 32 teachers. The result of this service activity is that teachers are starting to realize the importance of writing scientific papers to increase professionalism and improve students' abilities. Based on the results of interviews with teachers participating in the activity, information was obtained that further activities need to be held in the form of assistance in writing scientific papers.
\end{abstract}

Keywords: PKM activities; scientific papers; counseling.

\section{PENDAHULUAN}

Menulis merupakan salah satu keterampilan berbahasa yang dimiliki setiap orang. Menulis adalah suatu kegiatan yang mendeskripsikan dan merekonstruksi serta melakukan proses penemuan dan penggalian terhadap ide-ide yang ditemukan untuk menjadi bahan yang akan diekspresikan (Sukirman, 2020). Secara isi, karya tulis dibagi menjadi karya tulis ilmiah dan karya tulis non ilmiah.
Karya tulis ilmiah merupakan suatu karya tulis yang disusun secara sistematis menggunakan aturan tertentu berdasarkan hasil berpikir yang ilmiah (Marto, 2019). Contoh karya tulis ilmiah antara lain skripsi, tesis, disertasi dan artikel hasil penelitian. Sedangkan karya tulis non ilmiah adalah suatu karya tulis yang dihasilkan tanpa adanya prsedur dan hanya isinya hanya berdasarkan prasangka, penemuan secara kebetulan dan intuisi (Suryaningsih \& Kusmana, 
2018). Contoh karya tulis non ilmiah antara lain dongeng, cerpen dan komik.

Pada saat ini, guru dituntut harus menjadi guru yang profesional, dimana guru tidak lagi memiliki tugas sebagai pengajar namun dituntut pula harus memiliki kemampuan penggunaan ICT dalam kegiatan pembelajaran dan untuk menghasilkan berbagai karya (Juniardi, 2019). Salah satu karya yang dapat dihasilkan adalah membuat karya tulis ilmiah. Karya tulis ilmiah yang dihasilkan guru dapat diperoleh berdasarkan hasil penelitian terhadap peserta didik maupun manajemen yang ada di dalam sekolah. Karya tulis ilmiah yang dihasilkan oleh guru harus menyajikan fakta objektif, penulisannya cermat, harus sistematis, tidak melebih-lebihkan, tidak persuasif dan tidak mengejar keuntungan pribadi (Abduljabar \& Hidayat, 2013).

Keterampilan menulis karya ilmiah ini juga berguna bagi guru untuk kenaikan pangkat. Guru dituntut harus mampu mengumpulkan 12 angka kredit untuk naik golongan dari IVa ke IVb (PermenpanPANRB, 2009). Berdasarkan hal tersebut, maka penulisan karya ilmiah ini semakin wajib dilakukan oleh guru. Perubahan sistem angka kredit bagi guru membuat guru semakin kesulitan apabila tidak memiliki kemampuan dalam menghasilkan karya ilmiah. Guru juga terkadang memiliki pandangan bahwa bahwa menulis karya ilmiah merupakan suatu hal yang sulit (Marijan, 2012).

Pada dasarnya, guru memiliki modal yang diperoleh ketika guru berada pada masa pendidikan dahulu. Guru mendapat pembelajaran mengenai jenis penelitian dan model-model pembelajaran yang dapat digunakan untuk melakukan penelitian, khusunya penelitian tindakan kelas. Penelitian tindakan kelas adalah penelitian yang dilakukan oleh guru kelas di kelasnya sendiri melalui kegiatan refleksi diri untuk memperbaiki diri dalam mengajar sekaligus menyelesaikan permasalahan yang dihadapi oleh siswa (Wardani et al., 2019). Guru kelas dapat dengan mudah melakukan penelitian tindakan kelas karena guru tersebut mengetahui permasalahan siswa serta lebih mengenal karakteristik siswa yang ada di dalam kelas. Namun yang terjadi adalah sebaliknya, guru juga tetap tidak mampu dalam menghasilkan karya ilmiah dari penelitian tindakan kelas tersebut.

Berdasarkan hasil wawancara dengan Bapak Hakim Usman, M.Pd pada tanggal 12 Agustus 2021 selaku kepala sekolah SDN 1 Suka Makmur menyatakan bahwa banyak guru yang berada di sekolah tersebut mengalami kesulitan dalam menulis karya ilmiah. Hal ini disebabkan karena kurangnya sumber literasi dan faktor lingkungan Lebih jauh, guru-guru mengungkapkan bahwa karya tulis ilmiah bersifat teknis maupun teoretis sehingga mereka mengalami kesulitan bagaimana menulis karya ilmiah dengan baik dan benar, sementara pengetahuan dan pengalaman menulis sudah lama tidak dilakukan

Senada dengan penelitian yang dilakukan oleh Rohaeti (2013), narasumber juga menyatakan bahwa kesulitan guru dalam menuliskan karya ilmiah disebabkan oleh faktor guru itu sendiri. Guru menjelasakan bahwa mereka memiliki pengalaman yang sedikit dalam menulis karya ilmiah dan faktor semangat yang kurang. Lebih jauh, guru juga menjelaskan bahwa menulis karya ilmiah ini akan menghabiskan banyak waktu dan harus memiliki kemauan dan semangat yang kuat (Noorjannah, 2014) dan dilain pihak guru juga harus membagi waktu antara pekerjaan di sekolah dengan keluarga. Hal ini menyebabkan guru memiliki waktu yang sedikit untuk bisa melakukan penelitian.

Berdasarkan hasil wawancara tersebut maka, tim pengabdi PGSD UNRAM beserta guru-guru bersepakat untuk melakukan suatu kegiatan tentang penyuluhan karya ilmiah. Kepala sekolah SDN 1 Suka Makmur mengharapkan kegiatan penyuluhan ini tidak hanya melibatkan guru-guru yang ada di sekolah tersebut melainkan harus diikuti oleh guru-guru SDN yang berada di gugus VI Kec. Gerung. Penyuluhan ini diharapkan dapat membuka wawasan mereka lebih mendalam secara teoritis maupun praktis dan dapat digunakan dalam melakukan penelitian baik untuk kepentingan personal maupun lembaga.

\section{METODE}

Kegiatan pengabdian ini dilakukan pada tanggal 4 September 2021 dan masih berada masa pandemik covid-19 sehingga harus menerapkan protokol kesehatan. Kegiatan pengabdian ini dilakukan di SDN 1 Suka Makmur dan dihadiri oleh 38 orang yang terdiri dari 6 orang tim pengabdi dan 32 orang guru termasuk ketua gugus $\mathrm{VI}$, kepala sekolah dan guru kelas. Metode pemilihan lokasi yang digunakan pada kegiatan pengabdian ini terdiri dari komunikasi, koordinasi, observasi dan komunikasi. Metode yang dilakukan dalam kegiatan pengabdian ini adalah metode ceramah.

Metode pemilihan lokasi pengabdian dapat dilihat pada Gambar 1 di bawah ini. 


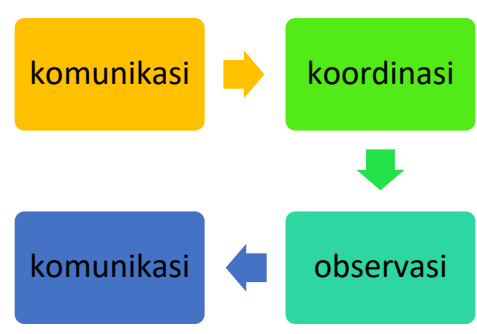

Gambar 1. Metode Pemilihan Lokasi Pengabdian

Kegiatan pengabdian kepada masyarakat ini bertujuan untuk memberikan penyuluhan kepada guru-guru yag berada di gugus VI Kec. Gerung tentang pentingnya penulisan karya imiah untuk meningkatkan keprofesional guru dan penyelesaian permasalahan siswa dalam menguasai pelajaran di kelas. Pelaksanaan kegiatan pengabdian ini dilakukan melalui pemaparan data oleh pemateri mengenai teknik menemukan permasalahan penelitian, ketatabahasaan karya ilmiah dan konsep penulisan karya ilmiah dan dilanjutkan dengan diskusi tanya jawab antara pemateri dan peserta pengabdian.

Pengumpulan data pelaksanaan kegiatan pengabdian ini dilakukan dengan observasi dan wawancara terbuka. Hasil dari kegiatan pengabdian ini dilakukan dengan cara mendeskripsikan setiap kegiatan yang terjadi selama kegiatan pengabdian berlangsung.

\section{HASIL DAN PEMBAHASAN}

Kegiatan pengabdian kepada masyarakat ini dilakukan di SDN 1 Suka Makmur Kec. Gerung, kabupaten Lombok Barat. Kegiatan ini bertujuan untuk melakukan penyuluhan tentang menulis karya ilmiah bagi guru-guru SDN gugus VI Kec. Gerung Kab. Lombok Barat. Kegiatan pengabdian berlangsung pada masa pandemi sehingga pelaksanaan kegiatan dilakukan menggunakan protokol kesehatan, khususnya mencuci tangan, penggunaan masker dan jaga jarak.

Kegiatan diawali dengan sambutan dari Mustafa, S.Pd yang merupakan ketua SDN gugus VI kec. Gerung dan dilanjutkan dengan pembukaan kegiatan yang dilakukan oleh kepala sekolah SDN 1 Suka makmur dan doa pembuka sebelum materi tentang penyuluhan penulisan karya ilmiah disampaikan secara bergantian oleh nara sumber. Materi pertama disampaikan oleh Dr. Ida Bagus Kade Gunayasa, M.Hum yang bertema teknik menemukan permasalahan penelitian dan ketatabahasaan karya ilmiah. Materi ini terdiri dari beberapa materi antara lain: penggunaan bahasa Indonesia yang baik dalam menuliskan karya ilmiah, penyebab rendahnya kemampuan guru dalam menulis, cara memilih judul penelitian, isi dan teknik menentukan topik, cara menemukan permasalahan yang ada di dalam kelas.

Pada materi pembuka, pemateri menjelaskan salah penyebab guru memiliki kemampuan yang rendah dalam menulis karya ilmiah adalah kurangnya literasi membaca dan banyaknya tugas administrasi yang harus dilakukan di sekolah. Kurangnya literasi membaca disebabkan karena kurangnya minat guru dalam membaca bahan bacaan diluar materi yang diajarkan disekolah. Selain itu guru tidak memiliki sumber literasi dalam membantu mereka dalam menuliskan karya ilmiah. Di lain pihak, guru merasa kekurangan waktu yang diakibatkan banyaknya adminisitrasi yang harus dikerjakan di sekolah.

Pada materi pemilihan judul, pemateri menjelaskan bahwa judul penelitian harus jelas. Dalam penelitian tindakan kelas, pemateri menjelaskan bahwa judul harus memiliki variabel input, variabel proses dan variabel bebas, sampel penelitian, tempat penelitian dan tahun penelitian. Pemateri juga menguji guru secara lisan untuk menentukan judul yang tepat untuk digunakan dalam kegiatan penelitian. Hasil pengujian secara lisan tersebut memberikan gambaran bahwa banyak peserta pengabdian yang salah dalam menentukan judul yang tepat. Adapun kesalahan yang dilakukan adalah memilih judul yang kelas penelitian belum ada, tahun pelaksanaan penelitian tidak jelas serta tidak memiliki variabel input untuk menyelesaikan permasalahan di dalan kelas. Adapun dokumentasi pemateri pertama dapat dilihat pada Gambar 2.

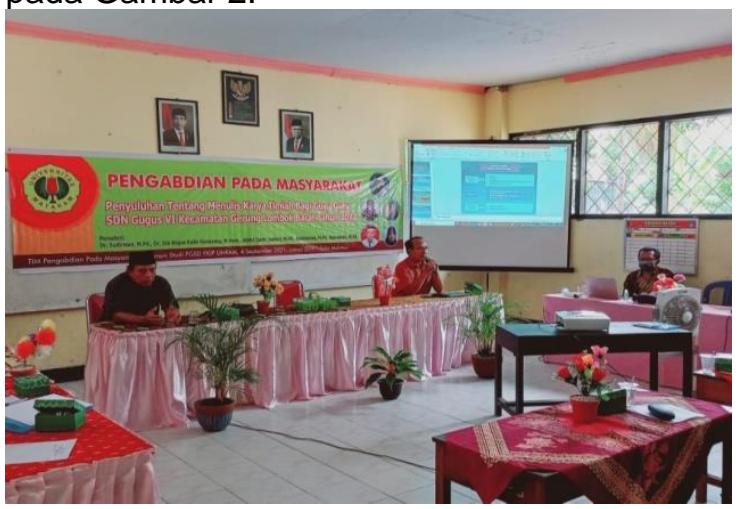

Gambar 2. Pemaparan Materi tentang kebahasaan penulisan karya ilmiah.

Materi Selanjutnya dilakukan oleh Dr. Sudirman, M.Pd mengenai konsep penulisan karya ilmiah. Pada bagian ini, pemateri terlebih dahulu menjelaskan materi mengenai karya tulis ilmiah dan karya tulis non-ilmiah. Karya tulis ilmiah memiliki terdiri dari skripsi, tesis, disertasi, kertas kerja dan artikel ilmiah, 
sedangkan karya tulis non ilmiah terdiri dari puisi, cerita pendek, legenda, dongeng dan sebagainya. Pemateri menjelaskan bahwa guru harus memiliki kemampuan dalam menulis karya ilmiah untuk meningkatkan kualitas serta mampu memenuhi tuntutan dalam kenaikan pangkat.

Pemateri menjelasakan bahwa kepada peserta pengabdian bahwa pengambilan tema penelitian dapat diambil berdasarkan permasalahan yang dialami oleh peserta didik di dalam kelas. Pemateri mengharapkan peserta pengabdian meningkatkan literasi baca, khususnya mengenai jenis-jenis penelitian yang cocok untuk digunakan di dalam kelas serta memahami model-model pembelajaran yang dapat digunakan untuk mengatasi permasalahan siswa di dalam kelas. Pemateri mengharapkan guru mampu menguasai dan menerapkan jenis penelitian kualtitatif dan kuantitatif.

Pemateri menjelaskan bahwa permasalahan siswa tidak akan diperoleh jika guru hanya mengajar di depan kelas. Pemateri mengharapkan agar guru-guru peserta pengabdian lebih peka terhadap permasalahan yang dihadapi siswa. Pemateri menyarankan agar guru di dalam kelas tidak hanya mengajarkan materi namun harus memberikan perhatian kepada siswa yang mengalami kesulitan. Setelah guru menemukan permasalahan yang ada di dalam kelas, maka hal ini bisa dijadikan bahan penelitian yang harus diselesaikan, sehingga guru dapat melakukan sebuah penelitian tindakan kelas yang bertujuan untuk menyelesaikan permasalahan tersebut.

Selanjutnya pemateri menekankan bahwa guru harus menguasai penerapan penelitian tindakan kelas (PTK). Pemateri menjelaskan bahwa PTK sangat penting untuk dilakukan di dalam kelas karena pada dasarnya PTK sangat membantu guru untuk menyelesaikan permasalahan siswa. Namun pemateri menjelaskan bahwa guru harus memahami bahwa hasil dari PTK di kelas yang satu tidak akan bisa digunakan untuk mengatasi permasalahan yang sama di kelas lain diakibatkan karena karakter siswa yang berbeda di setiap kelas. Adapun dokumentasi dari pemateri kedua dapat dilihat pada Gambar 3 dibawah ini.

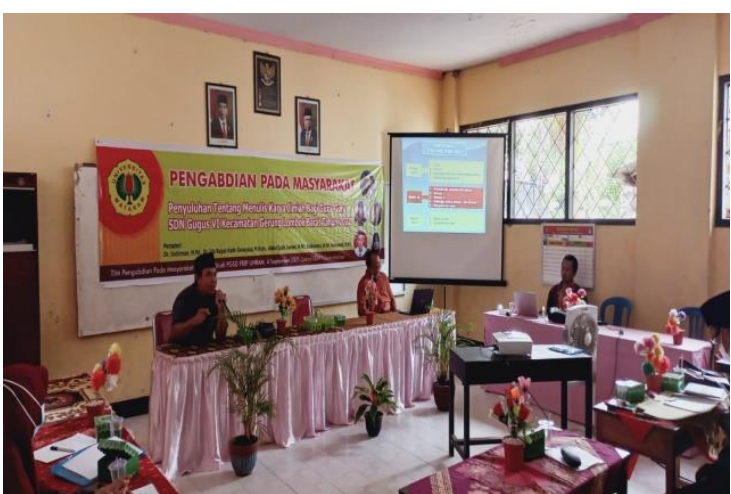

Gambar 3. Pemaparan Pemateri tentang Jenis Penelitian.

\section{Setelah}

pemateri

selesai menyelesaikan penyampaian materi, maka kegiatan berlanjut dengan sesi tanya jawab. Pada sesi tanya jawab, peserta bertanya mengenai hal-hal yang perlu dipersiapkan agar bisa memulai untuk menulis artikel ilmiah serta tempat untuk mempublikasikan artikel yang sudah selesai. Berdasarkan pertanyaan tersebut, maka pemateri menyarankan guruguru untuk meningkatkan literasi baca mengenai sistematika penulisan artikel. Melalui membaca sistematika artikel, maka diharapkan guru mampu untuk memahami latar belakang penelitian, model penelitian, penulisan hasil penelitian dan membuat kesimpulan dari penelitian yang telah dilakukan. Selanjutnya, pemateri juga menjelaskan bahwa untuk mempublikasi artikel yang telah selesai, guruguru dapat mengirimkan ke jurnal-jurnal yang ada di setiap universitas. Pemateri juga menginformasikan bahwa program studi PGSD UNRAM memiliki beberapa jurnal yang dapat membantu guru-guru untuk menerbitkan artikel yang sudah selesai. Adapun dokumentasi peserta yang bertanya dapat dilihat pada Gambar 4.

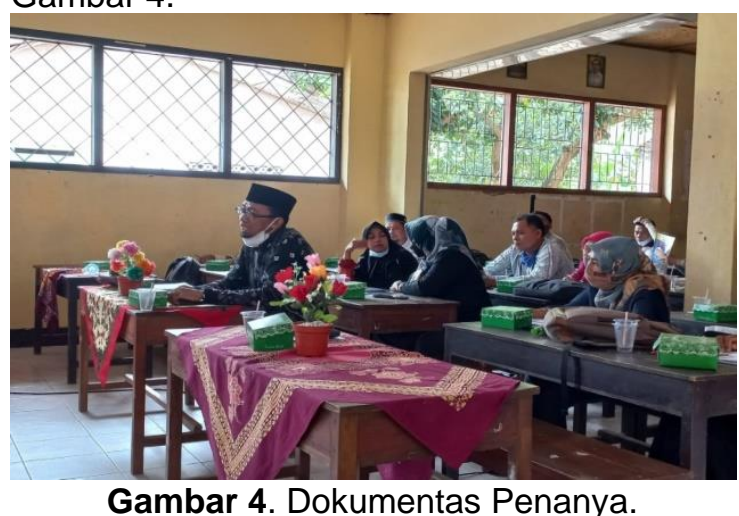

Setelah kegiatan tanya jawab selesai, maka kepala sekolah meminta kepada tim pengabdi agar melakukan kegiatan yang sama di sekolah tersebut namun dengan tema yang berbeda. Kepala sekolah meminta agar tim pengabdi untuk melakukan pendampingan 
dalam menuliskan karya ilmiah kepada guruguru pada kegiatan berikutnya.

\section{SIMPULAN DAN SARAN}

Berdasarkan hasil kegiatan pengabdian masyarakat dengan tema "Penyuluhan Tentang Menulis Karya IImiah Bagi Guru Guru SDN Gugus VI Kecamatan Gerung Lombok Barat Tahun 2021" yang dilakukan di SDN 1 Suka Makmur dapat diambil beberapa kesimpulan yaitu: guru-guru di Gugus VI Kec. Gerung sudah memahami cara pengambilan permasalahan untuk dijadikan karya ilmiah, guru-guru SDN di Gugus VI Kec. Gerung sudah mengetahui langkah-langkah melakukan kegiatan penelitian mandiri yang menghasilkan karya tulis ilmiah, guru-guru SDN di Gugus VI Kec. Gerung sudah mampu menemukan cara untuk mencari sumber pendukung dalam penulisan karya ilmiah. Namun, guru-guru juga membutuhkan pelatihan tambahan yang dapat membantu dalam menuliskan karya ilmiah dan guru-guru SDN di Gugus VI Kec. Gerung membutuhkan sumber literasi yang lebih banyak lagi untuk menunjang kemampuan dalam menuliskan karya tulis ilmiah.

Berdasarkan kegiatan pengabdian yang telah dilakukan, terdapat beberapa hal yang dapat disarankan dan ditindaklanjuti dari hasil kegiatan pengabdian di SDN gugus VI Kec. Gerung, yaitu: pihak sekolah harus menyediakan sumber literasi kepada guru untuk meningkatkan kemampuan guru dalam menuliskan karya ilmiah, pihak sekolah harus membantu guru dalam memfasilitasi penerbitan karya tulis ilmiah dan pihak sekolah mencari rekanan untuk memfasilitasi dan melatih guru dalam menuliskan karya ilmiah.

\section{UCAPAN TERIMAKASIH}

Ucapan terima kasih ditujukan kepada LPPM Universitas Mataram karena kegiatan ini dapat berlangsung karena ada dukungan secara moril dan materil. .

\section{DAFTAR RUJUKAN}

Abduljabar, B., \& Hidayat, Y. (2013). Karya Tulis IImiah dan Penelitian Tindakan Kelas Bahan Ajar pada Diklat PLPG. Bandung: Balai Diklat PLPG.

Juniardi, Y. (2019). Kesulitan Guru Sekolah Dasar Dalam Membuat Karya Tulis IImiah. Prosiding Seminar Dinamika Sekolah Dasar, 1(1), 1-7. Retrieved from https://journal.pgsdfipunj.com/index.php/p rosiding-seminar/article/view/176

Marijan, M. (2012). Cara Gampang Pengembangan Profesi Guru. Yogyakarta: Sabda Media.
Marto, H. (2019). Kesulitan Guru Sekolah Dasar Dalam Menulis Karya IImiah Di Kabupaten Tolitoli. Bomba: Jurnal Pembangunan Daerah, 1(2), 84-89.

Noorjannah, L. (2014). Pengembangan Profesionalisme Guru Melalui Penulisan Karya Tulis IImiah Bagi Guru Profesional Di Sma Negeri 1 Kauman Kabupaten Tulungagung. Jurnal Humanity, 10(1), 97114.

PermenpanPANRB. (2009). Permenpan Nomor 16 tahun 2009. Jakarta: Kementrian Negara Pendayagunaan Aparatur Negara Dan Reformasi Birokrasi.

Rohaeti, E. E. (2013). Budaya Meneliti di Kalangan para Guru Matematika dalam Meningkatkan Kualitas Pembelajaran. Prosiding Seminar Nasional Matematika Dan Pendidikan Matematika Stkip Siliwangi Bandung. Bandung: STKIP siliwangi bandung.

Sukirman, S. (2020). Tes Kemampuan Keterampilan Menulis dalam Pembelajaran Bahasa Indonesia di Sekolah. Jurnal Konsepsi, 9(2), 72-81.

Suryaningsih, N., \& Kusmana, S. (2018). Pengembangan Bahan Ajar Karya Tulis Ilmiah Berbasis Pendekatan Konstruktivisme. Jurnal Tuturan, 7(2), 884. https://doi.org/10.33603/jt.v7i2.1741

Wardani, O. P., Turahmat, T., Chamalah, E., Azizah, A., Setiana, L. N., Arsanti, M., ... Wijayanti, D. (2019). Pelatihan penulisan karya tulis ilmiah bagi guru-guru SD di desa Geneng kabupaten Jepara. Indonesian Journal of Community Services, 1(1), 116-125. https://doi.org/10.30659/ijocs.1.1.116-125 